\title{
The Education Facilities Procurement in Kindergartens in Yogyakarta, Indonesia
}

\author{
Tina Rahmawati \\ Department of Educational Management \\ Universitas Negeri Yogyakarta \\ Yogyakarta, Indonesia \\ tinarahmawati80@gmail.com
}

\begin{abstract}
The aim of this study was to describe various ways of procurement process in kindergarten in Yogyakarta, Indonesia. The study was descriptive qualitative research. The population of this study was kindergarten teachers. The data was collected by using interview and observation methods. The data validation-was measured by using resource triangulation. The collected data was analyzed by using Miles and Huberman method. The results showed that the procurement of facilities in Bantul Pembina State Kindergarten was conducted through various techniques such as purchasing, dropping from government, parents' contribution, making by themselves, utilizing surrounding environment, reconditioning, and utilizing internet. Otherways, the procurement of facilities in Kulonprogo Nanggulan State Kindergarten was conducted through purchasing, dropping, and making by themselves. Similary, the procurement of facilities in Wonosari Pembina State Kindergarten is conducted through purchasing, parents' contribution, making by themselves, and utilizing surrounding environment. On the other hand, the procurement of facilities in Candi Gebang Pembina State Kindergarten was done through purchasing, parents'contribution, making by themselves, utilizing surrounding environment, and taking advantage of the internet. At the same ways, the procurement of facilities in Glagahsari Pembina State Kindergarten was done through purchasing, parents' contribution, and making by themselves. The utilization of education facilities in State Kindergarten was focused on some aspects such as religion and moral development, rough motor development, physical health, science and knowledge, number development, alphabet, and socio-emotion of children.
\end{abstract}

\section{Keyword-Procurement, education facilities}

\section{INTRODUCTON}

The existence of tools of Kindergarten education is always related to the development of Kindergarten students. According to Permendiknas 58/2009, the development of Kindergarten students covers five fields as follows: (1) Moral and religion values, (2) physique (rough motoric, soft motoric, and health), (3) cognitive (science and common knowledge, shape concept; colour, size, and pattern, and the concepts of number, numerical symbol and alphabet), (4) language (receiving language, conveying language, and alphabet), and (5) socio-emotional.

In general, according to Permendiknas 58/2009, the procurement of education facilities in Kindergarten and Playgroup must fulfil three principles as follows: (1) safety, comfortable, bright, and fulfilling health criteria for children, (2) suitable with the level of children development, and (3) utilizing the potency and resource from surrounding environment including waste product/second-hand stuff which is still usable. Some facilities of Kindergarten education are in the form of educative game tool (Alat Permainan Edukatif/APE). APE is any game tool which contains educative values or can be used to educate kindergarten students (developing their belief in God, socioemotional, cognitive-intellectual, language, arts, and physical - soft motoric and rough motoric of kindergarten student). Alphabet material (alphabet and numerical symbol), story book which is read by teacher for students, story book which contains pictures, and the book which contains picture only which is read by teacher based on students' fantasy are also categorized as APE. The other education facilities are in the form of tool which is made by teachers, by students, or by factory/publisher. In daily life, there is possibility when teachers do not make tools since they do not have enough time and the cost is expensive.

The trade of learning tools and material itself actually contains philosophical and pedagogical problem which may not be realized and understood by teachers or the pertinent staff of Education Department. It is important to study and to research two problems of procurement and utilization of education facility (learning tool and material) of kindergarten student especially problem concerning teachers' creativity in designing education facility which is used as an attempt to develop "field of development of Kindergarten students" (belief in God, intelligence, socioemotional, physique, arts and language).

\section{METHOD}

The approach which was used in this research was qualitative approach with descriptive method. This research was conducted to explore the process of procurement and utilization of education facility (learning tool and material) of kindergarten students including problems in the process. Margono (2004) says that with the holistic research, the researcher in qualitative research needs sharp analysis (which has descriptive-analytic characteristic), objectivity, systematic and systemic analysis and therefore the researcher can get reliable interpretation. The parties that participated in this research as data resource were the principals and teachers of State Kindergartens in DIY. To obtain the data of the research, the researcher employed aids in the form of interview guide and observation guide. The interview was conducted to strengthen the data concerning procurement and utilization of education facility in Kindergarten. Observation was used as an attempt to observe the real activity concerning procurement and 
utilization of education facility in Kindergarten environment.

\section{RESULTS AND DISCUSSION}

\section{Procurement of Facilities in State Kindergartens in DIY}

There are many facilities in State Kindergarten Pembina which are procured by purchasing, receiving help from government and students' parents, making, reconditioning, and utilizing surrounding nature. Facilities procurement through purchasing becomes the school choice since this method is practical and there are many kinds and forms of tools in the market. The schools purchase the tools since the schools have fund which comes from APBD as BOP and monthly school dues (SPP) that is paid by students' parents.

In order to be effective, the facility procurement through purchasing must consider quality elements such as (1) durability, (2) endurance, (3) certain carefulness, (4) constancy, etc. These elements are suitable with the standardization of visual aid/playing kits in Kindergarten (2006:6). Therefore, in purchasing education tools/facility, it needs to determine detailed and clear specification concerning shape, size, type, material, and other desired characteristics. Playing kits can be obtained not only by purchasing but also by exploring and collecting materials from surrounding environment. According to [1], schools can categorize playing kits based on the function, the origin, development aspect that will be observed, and social aspect impact in the utilization of the kits.

The result of the research showed that teachers made the media by themselves. They made a media that would be used by students to plait by utilizing the box of milk package that was not used anymore. According to Mayke Sugianto (1995:56), playing kit can be obtained not only by purchasing it in toy shop but also by exploring and collecting materials from surrounding environment. Mayke Sugianto (1995:63) says that kids love materials that are combined to shape a toy or certain shape since they can feel exploration experience and find by themselves. Therefore, kids will achieve satisfaction and understandings through repetition.

In addition, teachers also procured facilities by reconditioning or fixing the broken facility. The recondition was used to fix tools such as table or chair which was broken yet repairable. It needs to pay attention to safety aspects such as shape or the use of paint on educative playing tools and furniture which is designed specifically for education in Kindergarten (1995:62).

Another result showed that teachers in State Kindergarten also utilized surrounding nature to procure education facilities. The material from surrounding nature was utilized in learning process according to the demand of recent curriculum. The materials from surrounding environment were categorized into natural material and material which was not used anymore. The examples of tools which were obtained by utilizing surrounding environment were gravel and marker pen which were used to develop counting aspect. Tree's yield and plants were used as media. This case was the example of utilization of surrounding nature in learning process according to the demand of recent curriculum. Teachers explored their creativity in making education tools by utilizing used materials and materials from nature environment. According to [1], there are many playing kits that can be obtained from nature environment in the countryside. The examples of these playing kits are seeds, bamboo, leaves, palm leaf rib, etc.

The procurement of education facility in state kindergarten was also conducted by receiving help from students' parents. In this case, the help was given by parents according to the demand from school party. For example, teachers asked students to bring fruits from home to be used in learning process concerning fruits. Teachers also made learning facility by themselves. Teachers made visual aid which was intended to introduce students to geometrical shapes. In this case, teachers utilized used material to make geometrical patterns.

According to standardization of visual aid/playing kit in Kindergarten which was established by the government (1996:4), visual aid/playing kit must fulfil education aspect which covers (a) suitability with the program of learning activity, (b) suitability with the level of ability of kindergarten students, (c) capability of stimulating kids' activity and creativity, and (d) capability of supporting the smoothness and the success of learning activity. The government established the standardization of visual aid/playing kit in Kindergarten (2006:9) which covers the field of development and habituation of moral and religion values, social values, emotional values, and independency which can be used in analysing the need of visual aid/playing kit in Kindergarten.

Teachers can conduct learning process outside classroom by explaining the material first and then asking students to come outside. Students are asked to utilize the condition in the environment as playing kit. According to Suratno (2005:83), learning process/playing can be conducted anywhere, anytime, and with any tool. Kids will have a chance to explore and experiment in learning and playing tool. The government established the standardization of visual aid/playing kit in Kindergarten (2006:31) which covers motoric/physique field which can be used in analysing the need of visual aid/playing kit in Kindergarten.

[2] kids' playing kit which is designed specially to be used in education process for pre-schooler is called educative playing kit. Educative playing kit has some characteristics as follows:

1) Having high level of safety.

2) Can be used repeatedly and cannot break easily. 
3) Designed to develop motoric skill and intelligence of kids.

4) Can be combined to form various forms according to kids' desire.

5) Can stimulate kids' creativity.

\section{CONCLUSION}

Playing kits in Kindergarten is very crucial education tool to support learning process in Kindergarten. The kit which is needed must be suitable and can facilitate the growth and development of kids optimally and comprehensively according to norm and life values. The condition of education facility especially playing kit in Kindergarten nowadays is various. There are quantity, kind, colour, and size of playing kit in Kindergarten which have not fulfilled the demand of learning process yet. There were many facilities in Pembina State Kindergarten in DIY which were procured through purchasing, receiving help from government and students' parents, making, reconditioning, and utilizing surrounding nature. There are many tools that can be used to develop motoric aspect of children. The various playing activities will broaden kids' motoric skill. The tools can be used inside or outside classroom. The use of visual aid is important in developing the aspect of physical health.

\section{REFERENCES}

[1] Mayke Sugianto. 1995. Bermain, Mainan dan Permainan, Jakarta : Depdikbud

[2] Suratno, 2005. Pengembangan Kreativitas Anak Usia Dini, Jakarta : Depdiknas

[3] Decker, Celia A., \& Decker, John R. 1988. Planning and Administering Early Childhood Programs. New York: Macmillan Publishing Company.

[4] Education International. 2010. Early Childhood Education: A Global Scenario. Brussel: Education International ECE Task Force.

[5] Gordon, A.M., \& Browne, K.W. 2013. Beginning Essentials in Early Childhood Education. $2^{\text {nd }}$ Edition. Belmont: Wadsworth.

[6] Jasa Ungguh M. 2009, Manajemen Playgroup dan Taman KanakKanak, Yogyakarta : DIVA Press.

[7] KFL\&A Public Health. 2014. Ready for Kindergarten. Kingston: KFL\&A Public Health.

[8] Norwegian Department of Education and Research. 2014. Framework Plan for the Content and Tasks of Kindergarten.

[9] Ontario, Elementary Teachers' Federation. 2001. Kindergarten Matters The Importance of Kindergarten in the Development of Young Children. Toronto: Elementary Teachers' Federation of Ontario.

[10] World Bank, The. 2012. "Indonesia: Development of the Young Helps Development of a Nation.” The World Bank Website. 